\title{
Identification of Rat Density and Ectoparasites in Seaport Area of Manokwari, Papua Province
}

\author{
Syamsuar Manyullei*, Muh. Fajaruddin Natsir, Anderson Batkunda \\ Department of Environmental Health, Faculty of Public Health, Hasanuddin University, Makassar, Indonesia
}

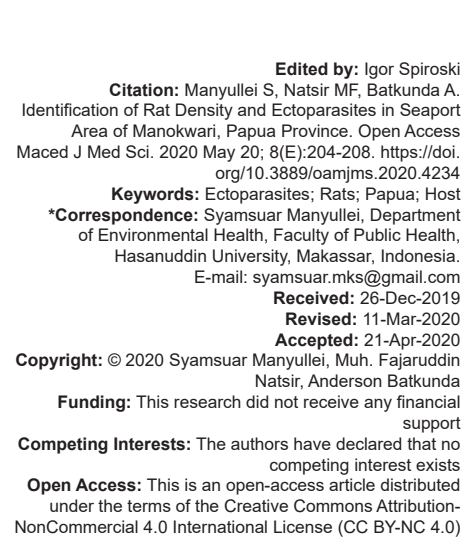

\section{Introduction}

Rats are wild animals that are often associated with human life. The high population of rats can have an impact on losses in various fields of human life. They also have a large impact on the health sector. In the health sector, rats can be a reservoir of several pathogens that cause disease in humans. Mouse urine and saliva can cause leptospirosis. Bite fleas on the mice body, can cause bubonic plague. In addition, mice can also transmit several other diseases including murine typhus, salmonellosis, rich psial, rabies, and trichinosis [1].

According to the annual report of the Manokwari Port Health Office (PHO) in 2017 serving 106 ships coming from abroad, 64 (60.38\%) ships came from infected countries and ships originating from healthy countries were $42(39.62 \%)$ ships. The rats and ectoparasites presence in the port area is a risk factor for public health problems. The risky locations at the port of Manokwari were in the port area or referred to as the area parameter. The perimeter area includes government offices, private offices, passenger terminals, container terminals, warehouses, and restaurants that should be sterile from various disease transmission vectors [2].

Rats and ectoparasites are disease transmission bridges from animal to animal as well as to humans, which have fatal consequences for humans. The seaport is one of the important factors that play a role in the spread of diseases that spread from one region to another. Based on annual reports at the Manokwari Class III PHO, the number of rats caught in 2017 was 201 with a $6.66 \%$ fleet index. The results of monthly activities carried out at Manokwari Class III harbor Health Office showed that the rat densities highest number in 2018 from January to November was 107 mice with a flea index of $15.19 \%$ [3].

The rats and ectoparasites presence in the port area is a risk factor for public health problems. This research can be used as early vigilance of rodent and vector-borne infectious diseases in ports related to rat density and ectoparasites. This research aims to determine the density description of mice and ectoparasites caught at Manokwari Harbor. 


\section{Methods}

This research was conducted from January 08, 2019, to February 08, 2019, in the Manokwari Seaport Area. This research is a qualitative study using a descriptive observational approach. The population in this study was all rats and ectoparasites around the rat catch-location, namely, the Manokwari Seaport. The number of samples taken was rats and ectoparasites which were successfully caught and found at the time of the study, which were 23 rats. Data collection was done through observation or direct observation at the location to be trapped. Data processing was based on the mice and ectoparasites identification result caught at the Manokwari Seaport presented in tabular and narrative forms.

\section{Results}

Based on the installation results of rat traps conducted for 4 days, three rat species were found, namely, Rattus tanezumi (52.17\%), Rattus norvegicus

Table 1: Based on species, gender, and mouse weight in the seaport working area of Manokwari

\begin{tabular}{lll}
\hline Description & $\mathrm{n}$ & $\%$ \\
\hline Rat species & 12 rats & \\
$\quad$ Rattus tanezumi & 10 rats & 52.17 \\
$\quad$ Rattus norvegicus & 1 rats & 43.47 \\
$\quad$ Cecurut (local species) & & 4.34 \\
$\begin{array}{l}\text { Genders } \\
\quad \text { Male }\end{array}$ & 13 rats & 56.52 \\
$\quad$ Female & 10 rats & 43.47 \\
Mice weight (g) & & \\
$\quad>70$ & 14 rats & 54.55 \\
$<70$ & 9 rats & 45.45 \\
\hline
\end{tabular}

(43.47\%), and shed species (4.34\%). Of the sexes, 13 male rats were caught $(13.55 \%)$ compared to 10 female rats (43.47\%). Quantitative identification results on rat body weight showed rats with body weight $>70 \mathrm{~g}$ were more commonly found 14 rats $(54.55 \%)$ and body weight $<70 \mathrm{~g}$ were 9 rats $(45.45 \%)$ (Table 1).

The research results showed a total success trap in two traps, namely, multi live trap A with 0.65 grilled coconut bait and multi trap B with 0.3 salted fish bait. While the calculation results of the success trap per day, in multi live trap A obtained values ranging from 0 to 0.13 and in multi live trap $B$ with salted fish bait ranging from 0.02 to 0.08 (Table 2 ).
The results showed that of the 23 rats that were caught, all found ectoparasites of 23 species

Table 3: Results of identification of ectoparasites in rats in the seaport working area of Manokwari

\begin{tabular}{|c|c|c|c|c|c|}
\hline \multirow{2}{*}{$\begin{array}{l}\text { Identification } \\
\text { date }\end{array}$} & \multirow{2}{*}{$\begin{array}{l}\text { Trapped mice } \\
\text { numbers } \\
\text { (rats) }\end{array}$} & \multicolumn{4}{|l|}{ Ectoparasites } \\
\hline & & $\begin{array}{l}\text { Fleas (Xenopsylla } \\
\text { cheopis) }\end{array}$ & $\begin{array}{l}\text { Small } \\
\text { louse }\end{array}$ & Louse & Ticks \\
\hline Day 1 & 11 & 10 & 1 & - & 3 \\
\hline Day 2 & 7 & 11 & 3 & 1 & 2 \\
\hline Day 3 & 5 & 12 & 3 & - & 1 \\
\hline Day 4 & 0 & - & - & - & - \\
\hline Total & 23 & 33 & 7 & 1 & 6 \\
\hline
\end{tabular}

of Xenopsylla cheopis fleas. Based on research, it is known that the general index value of fleas is 0.37 . According to the WHO (1988) and the Ministry of Health of the Republic of Indonesia, an area is said to be alert for the transmission of PES if the specific index for fleas $X$. cheopis $>1$ and the general index for fleas $X$. cheopis $>2$ (22) (Table 3).

\section{Discussion}

Ports and airports are the entry point of traffic of people and goods from countries and regions. This will certainly have an impact on the lifestyle, economy, and health level of the local community. The changes above also affect the pattern of disease transmission that occurs. One of them is the increasing cases of infectious diseases that have the potential as PHEIC (Public Health Emergency of International Concern).

Based on the research results during 4 days installation of traps with a total of 200 traps, the success trap calculation was generally obtained as an estimate of the relative density in an area. An area is said to have a high rat density if the success of catching more than $7 \%$; this means the density of rats in the port area of Manokwari is considered low. This can be caused by the perimeter area, in general, has applied the principle of rat proofing in buildings and warehouses so that the rat density is relatively low. Density apparently received serious attention from environmental psychologists. Density is a number of living things in each room unit. A situation will be said to be more density if the number of living creatures within a certain spatial boundary is greater than the area of its space.

Based on the research results, it was found several types of mice, namely, the rat species are $R$. tanezumi, R. norvegicus, and shaved species. These

Table 2: Success trap in the seaport working area of Manokwari

\begin{tabular}{|c|c|c|c|c|c|c|}
\hline \multirow[t]{2}{*}{ Execution time } & \multicolumn{2}{|l|}{$\Sigma$ Installed traps } & \multicolumn{2}{|l|}{$\Sigma$ Caught mice } & \multicolumn{2}{|l|}{ Success trap } \\
\hline & Multi trap A (pieces) & Multi trap B (pieces) & Multi trap A (rat) & Multi trap B (rat) & Multi trap A & Multi trap B \\
\hline Day 1 & 50 & 50 & 7 & 5 & 0.3 & 0.2 \\
\hline Day 2 & 50 & 50 & 5 & 1 & 0.2 & 0.04 \\
\hline Day 3 & 50 & 50 & 3 & 2 & 0.13 & $0, .08$ \\
\hline Day 4 & 50 & 50 & 0 & 0 & 0 & 0 \\
\hline Total & 200 & 200 & 15 & 7 & 0.65 & 0.30 \\
\hline
\end{tabular}


mice are mice that live in habitat, plots, warehouses, and sewers. R. tanezumi is the most caught rat in the port of Manokwari. Similar research results are also shown by research conducted at. Boyolali Regency, the species most caught, is $R$. tanezumi [4]. The rat is a sub-species of Rattus rattus commonly found in residential settlements [5].

As for the types of mice found, namely, $R$. norvegicus and Cecurut types, the presence of these mice indicates the working area condition of Manokwari Port which is not clean enough so that it can attract insects (e.g., cockroaches) into the Manokwari Port Office. The large number of rats caught in the working area of Manokwari harbor shows that the rat population in the region is quite high. As a comparison, a study in 2010 in the residential area of Sleman Regency showed that there were 17 rats that were caught. The high rat population in an area is one of the risk factors for zoonotic disease transmission, for example, leptospirosis [6].

Based on gender, male rats were caught more than female rats. Rat mobility aims to find feed, mate and orientation of the region. The male rat number that was caught indicates that these mice have high mobility.

The results of previous research stated that female rats were more easily caught than male rats, this was possible because the female can repeatedly come out of the nest to get food during pregnancy and lactation period so that females were more easily caught than males. Female mice act as feeders for their children while male mice act as guardians of the nest or its territorial area from predator attacks, so female mice tend to be outside the nest than male rats [7].

Based on the multi live trap A calculation results with 0.65 grilled coconut bait and multi trap $B$ with 0.30 salted fish bait. Setting traps using multi trap A with grilled coconut bait is still more effective than multi trap $B$ with salted fish bait, although the success value is not much different. While the calculation results of success trap per day in multi live trap A obtained values ranging from 0 to 0.13 and in multi live trap $B$ with salted fish bait ranging from 0.02 to 0.08 . This success trap was used as an estimate of the relative density in an area.

The difference in the catching success can be caused by trap factors with the type of bait, one factor is dependent on the sensitivity of the trigger. The multi trap model of the mousetrap is a type of trap that can catch more than one rat and is a trap that does not cause mice to die. However, this trap has two drawbacks, namely, mice that are caught first can get out of the trap with the help of other mice that step on the exit, but the second rat does not enter the trap while the mice contained in the trap can get out of the trap. Furthermore, the rats that step on the entrance will come out by walking backward. In addition, for mice that enter a large size, the rat will push the door until it is damaged so that the rat can get out.
Although the mice density in the perimeter area is lower than that of the buffer area, it is important to watch out for rat infestations from the buffer area. The rats roaming ability reaches a radius of 30 in the perimeter area of the Port of Manokwari (0.5). It can also be seen that the flea index in the buffer zone is higher than the perimeter region. Brooks and Rowe stated that one of the factors that determine the movement and development of mice is the source of food, water, and hiding place for the rat itself [3].

Laying traps also affect the success of catching mice. Traps were placed in a place that was thought to be a rat's way (runway) or often passed by rats that can be seen from signs of the presence of mice, such as in the kitchen or roof. This is because mice have thigmotaxis character, which has the same trajectory when looking for food, looking for nests, and other daily activities [8].

Based on the research results showed that from 23 caught rats, all found ectoparasites of 23 species of fleas $X$. cheopis, 1 louse, 7 small louse, and 6 mites. The discovery of various kinds of ectoparasites is often found in the body of mice. According to Brotowijoyo in Ristiyanto, it was mentioned that the phenomenon of one host (rat) found various types of ectoparasites at the same time was known as polyparasitism. Parasitism, like this, is usually caused by a host environment that is compatible with the ectoparasites [9].

Rats and fleas interact in obligate transient ectoparasites. In this interaction, adult fleas always live attached to the surface of the host's body, while the adult stage grows regardless of the host. This interaction is more flexible, unlike ticks (Anoplura) which persist throughout their lives in the body of mice. The interaction between fleas and hosts seems to be influenced by environmental factors (e.g. fleas habitat) and the adaptation ability of the fleas. Some types of fleas tend to have the same structure with their host. Several other types of fleas stick strong and long on the host skin until it is full of blood like how to eat a tick. Certain flea types penetrate the host skin to the epidemic layer, causing the skin to swell because it contains fleas that are full of blood. The term true host is often used to denote a single host or selected host which is considered to be the most important if a species of fleas occupies several types of hosts. The main host is the host which is suitable or matching for the continued reproduction of fleas in an unlimited period of time [10].

Fleas like mammals that live in fleas infected nests, holes, and caves. Dry air conditions have an unfavorable influence on the survival of fleas. Every $100^{\circ} \mathrm{C}$ rise in temperature, the life span of fleas is reduced by $1 / 2$ or $2 / 3$ of its normal life. The habits of fleas are greatly influenced by the host, so the presence of fleas in $R$. tanezumi caught in the house is very beneficial for fleas that cannot survive in humid places and low temperatures. 
The fleas density in the body of mice is commonly referred to as the General Fleas Index, which is to find out the average investment density of fleas found divided by the total number of mice caught in surveillance programs in the health field, often used for the general index of fleas and specific indices for fleas. This value, together with knowledge of the distribution of hosts, vectors, and their habitat, can predict human risk for contracting rodent-borne diseases such as bubonic plague in an area. It has been agreed that the general index of fleas is higher than 2 and the specific index of fleas is higher than 1 for $X$. cheopis in mice has the potential to transmit bubonic to humans [11].

The results showed that of 23 rats that were caught, there were 23 ectoparasites of $X$. cheopis fleas, 1 louse, 7 small louse, and 6 mites. The manifestation of rat vectors that have caught ectoparasite can be at risk of transmission of bubonic plague, murine typhus, scrub typhus, and others.

General characteristics of fleas $X$. cheopis type are brown colored body, flat on both lateral, do not have wings. The antenna location is in the gap in the head. It has three pairs of legs, hind legs longer than the front. The posterior part of the female has a rounded tip. Having a spermateka like a bag near the posterior end. In the male posterior, section has a tip like a spear pointing up. The ninth thumping has undergone a modification which forms a clamping device used during copulation, the aedeagus. In the ninth thumping in females and males, there is a dorsal sensory board called pygidium (sensilium), which is covered with feathers and hairs. Based on the shape, color, and characteristics of $X$. cheopis obtained at the port of Manokwari, the same as another study by Anam [9]. From the measurement results of body length and width obtained body length ranging from 1.9 to $2.6 \mathrm{~mm}$ $(2.30 \pm 0.250)$, with a width of $0.8-1.2 \mathrm{~mm}(1.03 \pm 0.141)$ on $R$. tanezumi [8].

The ectoparasite preference process for the host is through the adaptation phenomenon, both complex morphological and biological adaptations. This process can be started from the ancestor of the ectoparasite type, then derived to its progeny [12]. According to the theory of heterogeneity, ectoparasites and hosts are two individuals of different types and their origins. Although ectoparasites choose certain hosts for their survival, this does not mean that there are only ectoparasites in their bodies. A total of 13 male rats $(56.52 \%) 10$ female rats $(43.47 \%)$ were successfully captured during the study [13].

The phenomenon in one host (rat) found various types of ectoparasites at the same time is known as polyparasitism [14]. Parasitism like this is usually caused by a host environment that is compatible with the ectoparasite [15].

\section{Conclusions}

Based on the research results, it is concluded that the installation of traps carried out for 4 days from 20 to 24 February 2019 with traps installed 200 traps using salted fish and grilled coconut bait. A total of 23 caught rats with the species of rats caught were R. tanezumi $(52.17 \%), R$. norvegicus $(43.47 \%)$, and shaved species $(4.34 \%)$. These mice are mice that live in habitat, plots, warehouses, and sewers. The identification results of rats and fleas found ectoparasites of 23 species of $X$. cheopis fleas, 1 louse, 7 small louse, and 6 mites. The indicator measurement results of total success trap per day in multi live trap A obtained values ranging from 0 to 0.13 and in multi live trap $B$ with salted fish bait ranging from 0.02 to 0.08 .

It is recommended for the $\mathrm{PHO}$ Manokwari to disseminate information about their roles and functions at the port, especially to the authorities, managers, and certain parties so that the vector control program and activities in the working area of the PHO Manokwari can run and be well monitored.

\section{References}

1. Annashr, N. Study of rat and ectoparasites density in Jomblang village, Candisari district, Semarang city. Health Insights. 2017;3(2):68-76

2. KKP Manokwari. Annual Report of Manokwari Port Class III Health Office. Manokwari: Class III KKP Manokwari; 2017. https://doi.org/10.5220/0007513503140319

3. Priyotomo YC. Study of rat and ectoparasites density in the perimeter and buffer area of the Cilacap sea port. J Public Health. 2015;3(2):86-96.

4. Maulana Y, Rahma DI, Rahardjo J, Paramita D. Identification of ectoparasites in rats and shards in the focus area of the Suroteleng village, Selo district, Boyolali Regency. BALABA J. 2012;8(1):17-20.

5. Syamsuar M, Hasnawati A. Study on identification of rats and the existence of Leptospira bacteria. $\mathrm{sp}$ in the flood area of Puskesmas Tempe, Wajo district. Asian J Med Res. 2018;7(3):1-6.

6. Rusmini R. Dangers of Leptospirosis (Rat Urinary Disease) and How to Prevent it. Yogyakarta: Gosyen Publishing; 2011.

7. Tri R, Yunianto B. Reservoir and leptospirosis cases in extraordinary occurrence areas. Natl Public Health J. 2011;7(4):162-8.

8. Dina S, Ustiawan A. Species of shrews and fleas in the Banjarnegara city market, Banjarnegara Regency. BALABA J. 2013;9(2):39-46.

9. Anam K. Diversity and distribution of ectoparasites in rats in the regional hospital. AW Sjahranie Samarinda. Sci Media. 2016;9(2):123-30.

10. Arengga $B$, Dahelmi. Types of ectoparasites in small mammals found in Pasar Raya Padang, West Sumatra. J Biol Andalas Univ. 2013;2(3):169-74. 
11. Asyha T. Biotic environmental factors in leptospirosis. BALABA J. 2009;5(2):26-7.

12. Ristiyanto R, Polynesia R. Ectoparasites diversity index in rattus tanezume temmick. J Vector. 2009;1(2):73-84.

13. Hannah MH, Brock MF. Relationships between roots preferences, ectoparasite density, and grooming behavior of neotropical bats. J Zool Lond. 2005;266(4):333-40.
14. Soejodi H. Control for a quarantine action. J Environ Health. 2013;2(1):23-66.

15. Ministry of Health Republic of Indonesia. Pes Contro Technical Guidelines. The Indonesian Ministry of Health, Directorate General of Communicable Disease Eradication and Environmental Sanitation. Jakarta: Ministry of Health of the Republic of Indonesia; 2014. https://doi.org/10.25133/ jpssv27n1.003 